\title{
Indi@logs
}

Vol 8 2021, pp 29-49, ISSN: 2339-8523

https://doi.org/10.5565/rev/indialogs.170

\section{THE INFLUENCE OF GANDHI'S ECONOMIC THOUGHTS ON THE INDIAN ECONOMY}

\author{
TAZ MAZINDER BARUA \\ Gauhati University, Assam \\ tony20001980@gmail.com
}

Received:19-10-2020

Accepted:02-02-2021

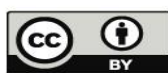

\begin{abstract}
Gandhi wanted the Indian economy to center around autonomous village republics rather than work on the back of large-scale industries or consumption expenditure. Gandhi's principles for formulating his economic thoughts were based on a call to 'return to the nature'. He would have liked people to reduce their wants in lives and to concentrate instead on development of their faculties for achievement of spiritual goals. This would not require people in villages to madly rush to cities in search of work. All people would live more fulfilling and meaningful lives. He would justify use of machines and industrial production systems in the economy only when the outcomes serviced the fundamental and most basic needs of people. This paper describes Gandhi's economic principles in order to analyze how they contrast with the free operation of the market today which has created multiple new inequalities in society. The liberalized rapid economic growth model in India has made development of the rural sector secondary to rapid growths in trade and manufactures of consumer commodities in the urban centers. This has gone the opposite way from the paths Gandhi outlined for his country, and it has exacerbated the same societal inequalities he wanted to see reduced.
\end{abstract}

KEYWORDS: self-sufficiency; gram swaraj; Gandhian economics; rural development; economic liberalization

RESUMEN La influencia de los pensamientos económicos de Gandhi en la economía india

Gandhi quería que la economía india se centrara en las repúblicas de pueblos autónomos en lugar de trabajar sobre la base de industrias a gran escala o de costos de consumo. Los principios de Gandhi para formular sus pensamientos económicos se basaron en una llamada a "regresar a la naturaleza". Le hubiera gustado que la gente redujera sus deseos mundanos y se concentrara en cambio en el desarrollo de sus facultades para el logro de metas espirituales. Esto no requeriría que la gente de las aldeas haya de apresurar locamente a las ciudades en busca de trabajo. Todas las personas vivirían vidas más satisfactorias y significativas. Justificaría el uso de máquinas y sistemas de producción industrial en la economía solo cuando sus resultados satisfagan las necesidades fundamentales y más básicas de las personas. Este artículo no se detiene en los principios económicos de Gandhi, sino que analiza cómo se contrastan con el libre funcionamiento del mercado que hoy en día crea múltiples desigualdades en la sociedad. El modelo liberalizado de rápido crecimiento económico en la India ha hecho que el desarrollo del sector rural sea secundario al rápido crecimiento del comercio y la fabricación de productos de 
consumo en los centros urbanos. Esto ha ido en sentido contrario a los caminos que Gandhi delineó para su país, y ha exacerbado las mismas desigualdades sociales que él quería ver reducidas.

Palabras Clave: autosuficiencia; gram swaraj; economía de Gandhi; desarrollo rural; liberalización económica

\section{Introduction}

Mohandas Karamchand Gandhi is renowned for his critical thinking in the field of spirituality, political philosophy and for his role in steering the national liberation struggle in India to success through the use of a unique non-violent and passive method called the Satyagraha. However, Gandhi was also a deep thinking economic philosopher. He left considerable literature and notes on his economic thoughts which have enabled us to explore the economic model he outlined for adoption in India after independence from colonial rule.

The Gandhian economic plans were not fully implemented by the government after the independence of India. However, his economic thoughts continue to influence and guide the formulation of policies in legislative and administrative processes. Gandhi's economic thoughts were one of the main guiding motivations during the freedom struggle. Gandhian ideals formed the moral framework upon which the substance of the liberation movement was constructed. As the freedom movement progressed into the 1930s, the chief leaders of the Indian National Congress such as Jawaharlal Nehru and Subhas Chandra Bose were impressed more with the success of centralized planning in the USSR (Union of Soviet Socialist Republics) and the development of large-scale machines to propel economic growth in India. From the 1930s, the economic ideas of Nehru and Bose began to receive more support within the Congress. Gandhi's ideas were regarded as moral principles but were seen to be impractical for immediate implementation. Gandhi's economic thoughts, therefore, did not substantially contribute to the development of an economic model in post-independence India but it exerted influence on all areas of government action and some aspects of economic planning.

Gandhi was committed to the ideals of decentralization. He believed an economy constituted by networks of village republics spread all across India was more powerful for generating national prosperity and happiness than a centralized economy. Moreover, it was his lifelong claim that the 
economy he envisioned was suited to the traditional temperament of Indian people who were naturally conditioned to develop spiritually rather than materially. The economy of village republics would produce only for the sustenance of the village and for trade of the surpluses with neighboring villages. Villagers would not consume anything they did not require for the basic essential functions in life. In Gandhi's time, the model for such self-sustaining villages already existed throughout the countryside in India. He used the model to explain the differences between Indian civilization and western culture. Whereas western economies were designed to supply human greed, desires, and wants, Indian civilization was characterized by the opposite, that is, traditionally Indian people were voluntarily leading frugal lives to save their energies for spiritual development. "To Gandhiji, civilization in the real sense of the word consisted not in the multiplication of wants but in their deliberate and voluntary restriction" (Chowdhry, 1988: 198).

Gandhi was opposed to technological developments and the use of machines by people in India on the same principles. Its use was acceptable only when machines led to the fulfillment of basic human needs. For example, to him, industries that insisted on saving labor were representations of human greed. However, if the same industries were run for the goals of generating productive employment for the poor, the running of the industries was acceptable to him. Western civilization with its complacency and what was seen as sophisticated material lives he found highly inconsistent with the development of human qualities necessary for high thinking. His economic philosophy centered on a call to 'return to nature'. This he borrowed from the works of Plato, Rousseau and Tolstoy. Like Tolstoy, Gandhi was attracted to rural settings, living minimally, and living off one's hard labor. Like Plato and Rousseau, he believed in giving back to the community. An individual could truly prosper only when he or she was fully immersed in serving his or her community, producing only as much as was required to support basic life activities, and giving up the rest for the benefit of the community.

From Gandhi's perspective, the primary and basic units of the economy were its villages rather than its industrial sites or urban centers. The development and growth of rural sector industries 
could not depend on the growth of urban centers or industrial production sites (Nanda, 1994). Neither should it be necessary for people to migrate to urban centers to look for jobs. He wrote:

My idea of village Swaraj is that it is completely republic, independent of its neighbors for its own vital wants, and yet interdependent for many others in which dependence is a necessity. Thus every village's first concern will be to grow its own food crops and cotton for its cloth...then if there is more land available, it will grow useful money crops" (Misra \& Rajiv, 2002: 208).

This paper illustrates the economic ideas of Gandhi and then lays out the contradictions in the working of the contemporary liberalized economy in India with the concept of the Gandhian welfare state. After Indian independence, the influence of the Gandhian model on economic planners was overshadowed by the dominance of the preference for accelerated economic growth through centralized planning of the economy and rapid industrialization. Freedom fighters and politicians in newly independent India swore by Gandhian principles and they were morally committed to the Gandhian ideals. However, the political elite decided that the paths of industrialization and modernization were a more practical approach for improving the quality of the lives of Indians. Gandhi's economic thoughts, thereafter, came to constitute only a moral foundation subscribed to by the State. State policies in the social sector and allied improvements such as in the areas of development of cottage industries, improvement of cattle breeds, and eradication of poverty were developed with guidance derived from the Gandhian ideals.

Larger economic programmes instituted for industrialization and modernization of the country diverged from the Gandhian vision of the economy. The decisions for these programmes, undertaken from a socialist perspective, were ratified by the majority of political leaders led by Prime Minister Nehru. It allowed for constituting an alliance between the socialist goals of Nehru and the more radical socialist views of Gandhi. The political economy worked until the 1990s under the operation of this alliance of socialist views in India. However, since taking up liberal reforms in the economy in the early 1990s, the welfare state model in India has been undergoing changes. Gradual withdrawal of the state from interventions in the market has sharpened societal inequalities and exacerbated differences between the rich and the poor and between other social groups in society. 


\section{Gandhian Philosophy and his Economic Vision}

Gandhi's views on the model of the Indian economy were shaped by his overall political and social views and naturally by his philosophical and spiritual ideas on the 'right path for India'. Gandhi did not separate his economic ideas from his general thoughts on the scheme of things he thought best for the material and spiritual progress of the people of India.

One gets a clear illustration of Gandhi's views on economic strategies for the country from his writings on the right economic conduct. Gandhi disapproved of conducts that were driven by human greed for greater and more rapid economic production. To him, the use of machines and industrial production was justified only when it benefitted an individual's need for basic and selfsustaining economic activities. A key offered for applying the Gandhian approach to problems of society was written in these terms:

I will give you a talisman. Whenever you are in doubt, or when the self becomes too much with you, apply the following test. Recall the face of the poorest and the weakest man whom you may have seen, and ask yourself, if the step you contemplate is going to be of any use to him. Will he gain anything by it? Will it restore him to a control over his own life and destiny? In other words, will it lead to Swaraj for the hungry and spiritually starving millions? Then you will find your doubt and your self melting away (Gandhi, 1954: 88-89).

This key to Gandhi's economic thoughts -a deep empathy for the poor and the weak- explained his near-disdain for mechanical economic production systems. The outlines for these thoughts were laid out in 1909 in the Hind Swaraj, Gandhi's influential book describing the blueprints for the future course of the Indian freedom struggle and his thoughts on the basic divides between western and Indian civilization. In Gandhi's own words the book "was a severe condemnation of 'modern civilization"' (Gandhi, 1933: viii). In 1924, he made his position on modern economic mass production systems clearer. He objected to the craze of factory owners for owning and operating labor-saving machines. He did not object to the discovery and production of machines that enhanced the productivity of individuals. The use of some machines was justified since small machines, and manufactured tools, such as spectacles, the spinning wheel, and the cultivator's plough were basic. These machines improved their owners' lives and it was even essential for the healthy sustenance of people. Gandhi wished for the system to reverse. He was 
of the opinion that time and labor needed to be saved for all, not only for a fraction of humankind. Similarly, he certainly would have people make money and not live by spiritual devotion alone; but he would have this wealth concentrated in the hands of all rather than in the possession of a small minority (Gandhi, 1933).

Gandhi did not hesitate in identifying himself as a socialist, and the contours of his socialist views of society were provided to the public from his earliest writings. In his view, industries would be necessary for the Indian economy to provide the basic machines necessary for all people in India. Factories making such machines needed to be nationalized. His principle was that factories should be committed to saving unnecessary hard labor, and factories should not be oriented to satiating human greed. The State should protect individuals from the exploitation of their labor and the State should encourage self-sustenance through productive use of one's labor. The State should not permit the use of machine production systems for the creation of private wealth and it should not allow industrial civilization to hold back individuals from the achievement of the spiritual purposes of life.

Indian civilization, to Gandhi, was a timeless expanse of learning the merits of steadiness of spiritual purpose. Under the British colonial rule, Indians were considered uncivilized and ignorant by westerners, but, in reality, Indians were holding firmly to their civilizational ideals of right conduct, the performance of duty, and morality in life. Indian ancestors had set limits to indulgences and unbridled human passions. Gandhi was also of the opinion that in the twentieth century an uncontrolled indulgence of human passions and desires was the mark of Western civilization. In contrast, since Indians were guided by spiritual virtues rather than by passions, common people in the villages were independent of the urban economy. Urban centers had been places of relative evil even in the pre-modern period but people in rural pre-modern India were free to practice agricultural production without interference from the State. To Gandhi, the introduction of the railways and modern machines by the British for generating surpluses were civilizational vices. It corrupted the spiritually minded thinking of Indian people. Gandhi cited R.C. Dutt, a historian who wrote the Economic History of India and provided early intellectual leadership for the freedom movement, to also point out that introduction of modern mechanical 
production systems by the British destroyed indigenous industries such as handloom and handicrafts by flooding the markets with machine-made goods from Manchester (Gandhi, 1909).

Gandhi then went on to claim that Indian people had been impoverished by the introduction of the machine production systems. For this reason, he was severe in his criticism of western modernization and path of economic development, going to the extent of calling it evil by design. He observed that workers were enslaved in textile and other mills in India. The working conditions of women were deplorable. The strictest criticism was reserved for causing moral deprivation of the working class through severing them from spiritual goals of life and community service and subjecting them to lives of misery. Prospects of growth of the millsindustry increase in factories, and creating wealth for its owners were not attractive ideas to Gandhi. Mill-owners, and by extension all owners of industries, were no icons or stars of the national economy; and the mental condition of industry owners was something to be pitied because such owners were considered victims of greed (Gandhi, 1909).

Some elements of his vision one might call too simplistic. For example, Gandhi idealized the situation in India before all modern machines had been introduced. "What did India do before [modern machine-made] articles were introduced? Precisely the same should be done today. As long as we cannot make pins without machinery, so long will we do without them" (Gandhi, 1909: 82).

These Gandhian ideas contrasted the Indian conditions with the temperament of people in the West. He was successful in showing the fundamental differences between the economic thoughts of people in India and of people in the West. This had a great influence on the strategies of the freedom movement in India. The Indian traditions were adopted into the political programmes of the movement. The importance of Swadeshi or domestic production was stressed. Home-grown cotton was to replace foreign machine-made clothes. The simple beauty of hand-made earthen lamps was to substitute for the splendor of glassware. Programmes were started to give up foreign goods and to boycott their trade in India. In its place, the capacity of rural handicrafts to supply domestic economic needs was measured. In one sense, the pillars of his economic ideology were reliance on the simple basic functions of economic production. He highlighted the 
distinctions of the Indian traditional system from the modern West's economic model. In his view, the West's economic growth model depended on a base of labor-saving production systems, on capital appreciation through private investments, and on the use of machines for rapid mass production. Gandhi would have his country's economy grow on the strength of the hard honest labor of Indians for the sake of household self-sufficiency rather than for generation of surpluses.

The problems of the countryside, thus, were the central problems in the Gandhian scheme of things. Urban centers were distractions, if not downright morally evil, because concerns for human comforts and the use of machines to save excess labor and capital moved the industrialized urban economy. The development of cities was bound to impact the rural economy. Industrially produced goods would depress prices in the countryside. On the other hand, there would be a flight of capital from rural areas to urban areas if village landlords invested their surplus capital in the cities. The rural sector was to ultimately lose access to capital (Jodhka, 2002). He concluded by these arguments that the rural sector was supporting the expansion and growth of the cities. Gandhi would have this link reversed so that only the most essential machine production continued to operate. The State ought to have within its control the manner of its operations and the investment of capital. In the ideal Gandhian economy, the State was required actively to support only village economic production, but even in this, the goal was limited to the achievement of full local self-sufficiency. There was no bar on trade or movement of village production to cities but the necessity of city-made machine items in the villages would be minimal.

On the question of capital appreciation and wealth creation, Gandhi was of the view everyone should be paid equally for each honest day's work, but he also did not preclude anyone earning more than the most essential income (Rivett, 1959). However, he did have the opinion that the bulk of the greater earnings of an individual morally should be devoted to good of the community. He granted the State the responsibility to intervene in matters of administration of wealth and wealth ownership transfers. The rich ought to own wealth only as trustees. At the same time though, Gandhi recognized not only property rights, but also diverged from the Soviet 
experiment of the State indulging in the use of force for administering personal properties. In the Gandhian scheme, the rich should be self-motivated to give away their superfluous incomes.

The solid well-knit Gandhian economy was designed to work for the spiritual evolution and personal development of India's poorest people. It linked material requirements of local populations with local economic production in the rural communities. The Gandhian scheme was designed to generate from within the communities standards of living that could be accepted by all. The principle of trusteeship was key in this. Various members of the community were to form a community link so that the better-off might help the poor develop their faculties and express fully their personalities. One might consider these organic links Gandhi described not in terms of money or materials but in terms of the potential of local people to improve their creative productivity (Kumarappa, 1951).

\section{Gandhian influences in the Modern Indian Economy}

The economic thoughts that influenced the working of the Indian economy after the independence of India and after Gandhi's death in 1948 were western and industrial in character (Chowdhry, 1988). Moreover, multiple conflicts of opinion, methods, and strategies in the economic sphere weighed upon decisions of the government. Gandhi's economic thoughts had an independent force of influence on decisions of the Indian National Congress's political programmes and later on the independent Indian government. Since Gandhian considerations were entirely different from the considerations of Western economic thought, it was certain to Indian political leaders that concepts of the welfare state in the west and Gandhi's ideas of economic policy for India diverged. The challenge was in reconciling the approaches of the two diverging concepts, so that even though the Western welfare state concept seemed to have a greater influence on Indian economic planners after independence, Gandhi's approach could continue to guide strategies for resolving national domestic problems.

Prime Minister Nehru was dominant amongst newly independent India's economic planners. He had been one of the most prominent Congress leaders and a trusted aide of Gandhi. Nehru had firm faith in centralized planning, and saw in it the solution to achieving all-round economic 
development and removing Indian people from poverty. The influence of Nehru on national economic planning, and support from political leaders for his ideas underlie changes taking place in ideological preferences of the Congress between the period 1936 and 1940, and the emergence of tensions within the Congress to transform the party into a multi-class party (Chakrabarty, 1992). One might observe that Gandhi and Nehru were not far apart in their thoughts on economic planning. Both strove to introduce socialist planning in the country to create a society "with equal economic justice and opportunity for all, a society... for the raising of mankind to higher material and cultural levels" (Chakrabarty, 1992: 281). Nehru's vision of mechanized industries running the wheels of the economy in India and large-scale projects generating power and fuel appealed to the majority of national leaders, who saw Nehru's goals as necessary attempts "to transform India from an agricultural civilization with classical antiquity to an industrially advanced society" (Chakrabarty, 1992: 280).

In this, Nehru greatly differed from Gandhi. The emphasis on massive industrialization caused discomfort to Gandhian leaders, or the political camp that wanted more practical implementation of the Gandhian schemes. A compromise solution was arrived at to satisfy both the Gandhi and the Nehru camp of thought. This was that large-scale industries would co-exist in independent India and there would be active State support for the development of rural sector cottage industries (Chakrabarty, 1992). Nehru's goal was the attainment of national economic selfsufficiency through rapid industrialization and centralized planning whereas the Gandhian camp wished for every village to attain economic self-sufficiency by relying only on local production and by satisfying in rural households only the most basic needs.

The development and gradual evolution of the Nehruvian economy in the early decades after independence were accompanied by concurrent changes in Gandhian economic ideology. With Gandhi's death in 1948, his intellectual followers and his political supporters advocated for his economic schemes. Two branches of thought emerged in the post-Gandhi period -a rigid version was associated with Gandhian economists like JC Kumarappa, while a moderate version of it evolved which did not strictly oppose industrialization, but only opposed interference of the urban sectors in the rural economy. 
The influence of the moderate stream of Gandhian thought was seen in the adoption of an economic policy by the Indian government that favored rapid industrialization while protecting the village industries. Large-scale industries could not employ all the labor force but the rural industrial sector could employ large numbers of villagers. There was "no possibility in the short run for creating much employment through the factory industries". On the other hand, household or cottage industries required very little capital, so that in the rural industrial sector "about six or seven hundred rupees would get an artisan family started" (Nachane, 2016: 23). Indian economic planners calculated that employment possibilities generated by investments in the rural industrial sector was up to twenty times greater than employment opportunities generated in the large industries. It was also said that the use of such Gandhian schemes endeared the national economic development plans to the masses by causing them to immediately benefit from outcome of these plans.

Further, the small-scale and cottage-industry sectors were protected from competitive harm caused by large-scale industries. The State implemented restrictions on imports, strict licensing requirements for large-scale industries, and it reserved certain production items for the cottage industries. The influence of Gandhian thought one could also observe in the State restricting imports of luxury consumptions and restraining domestic production of luxury goods. One might also identify the influence of Gandhi's ideas of trusteeship by the rich in the existence of high personal income tax rates and high corporate taxes in the early post-independence period.

From the 1970s onwards, special attention was directed to rural sector development and poverty alleviation schemes. Gandhian principles were often invoked in programmes of the State for interventions in the rural economy. However, these programmes were not always successful, and from the 1980s, the failures of the socialist schemes under implementation began to be pointed out.

\section{"Gram Swaraj" in the Modern Indian Economy}

Achievement of the targets of improving self-sufficient village economies was always a challenging goal for India's planners. However, many Indians associated with this vision because 
the success of these goals was understood to be at the core of India's civilizational questions. As Gandhi had written two decades before the achievement of national liberation, "we are inheritors of a rural civilization. The vastness of our country, the vastness of the population, the situation and the climate of the country has, in my opinion, destined it for a rural civilization" (Parikh \& Petrie, 2019: 1). However, the historical sentiment contained in Gandhi's vision soon got mixed up with the more influential economic schemes of Nehru which sought the development of a centrally planned modern economy running on the backs of heavy machinery and technological advancements.

Gandhi remained unchanged in his lifetime in his commitment to advocating towards selfsustaining villages or gram swaraj as his concept came to be known. In this, he was not unaffected by criticisms of his idealization of village economies, especially as political adversaries such as the champion of the Dalit community in India, B.R. Ambedkar, construed the rural settings in India as the hub of caste-based exploitation. Traditionally, geographies of villages were organized in India according to caste-based hereditary specializations, and it was in the villages that Indian society took upon its most complex forms (Parikh \& Petrie, 2019). Gandhi admitted to the existence of social problems in the villages but he remained convinced that a national economy centered on the rural-sector was ultimately a boon for everyone. $\mathrm{He}$ communicated these convictions to Nehru in 1945:

...Even in a rural civilization, there is no one 'ideal village', but a multitude of villages of different sizes and functions, developed organically, playing different roles for their inhabitants and those of other settlements both nearby and afar. We must also keep in mind that social complexity at rural settlements has many forms, and can take an ugly turn (Parikh \& Petrie, 2019: $15)$.

Gandhi's intellectual convictions precluded his grasping the ugly possibility of caste-exploitation persisting in economically advanced village societies. To Gandhi, economic rationality would ultimately trump social anxieties and lead villagers to join together on equal terms for selfgoverning the village and for conducting community activities such as educating children and maintaining public halls and theatres. This was almost too utopian for Indian economic planners to embed in planning schemes after independence. The planners did borrow from the Gandhian concern for the rural, the poor, and the neglected sections of society, and they made the 
eradication of such social problems in the villages of India central concerns of national economic planning. Public policies aiming to dispense equality of opportunities and economic justice, and policies aiming to resolve the most basic problems of hunger, nutrition, health, poverty, and employment generation were top priorities of government; and one might say these goals were derived from the vision of the father of the nation. The Gandhian welfare state ideas came to be seen in real terms through the support of the government for rural-sector production. The State took upon itself the responsibility for decreasing the gap between 'haves' and 'have-nots'. The State would ensure there was no exploitation of any human by another human.

One of the first instances of Gandhian socialism and his welfare state concept getting applied to society was a movement called the Bhoodan movement. It was started by a popular leader and disciple of Gandhi called Vinoba Bhave soon after independence. Bhave got rich or absentee landowners to gift their lands to their real cultivators or sharecroppers (Iyengar, Doshi \& Desai, 2012). The Bhoodan movement was an important example of the application of Gandhian economic strategies. It showed that the Gandhian ideology recognized property rights. It was clear that no coercion or undue influence or even legislative actions to get landowners to give up rights on lands were used. The movement wished only to reduce inequalities between richer landowners and poorer sharecroppers. Attention was drawn to the Gandhian cause of doing justice to 'dignity of labor'. Other than Bhave's movement, concurrent land reform programmes run by the State in the 1950s and 1960s to free land for redistribution to landless people can also be said to draw inspiration from Gandhian thinking.

The ideal Gandhian rural economy was projected to become independent of government resources, and it was to prosper by the local surpluses it generated. The village was to plan its own paths to development. This Gandhian goal contrasted with the working of Nehru's centralized planning model.

One might have expected that the government would have taken the rural sector into its confidence before planning resource allocations and the development paths for the sector. Although the government developed massive national programmes for the benefit of the rural and agricultural sectors, from the mid-1980s landowning farmers'organizations in the west and 
north of India began to demonstrate demanding democratization of the planning process. It asked for an increase in entitlements for farmers and the elimination of urban biases in public policies. One might observe in the revolt of this rural sector against centralized planning an alliance of views with the Gandhian ideology of autonomy for the rural sector. The farmer movements demanded the liberation of the agricultural sector from government controls. It was contended, as Gandhi too had indicated, that the rural sectors were indirectly supporting the faster growth of the urban economy.

Some of the farmer protests of the 1980s took new directions to oppose the economic reforms introducing globalization in India. Some militant tactics were used such as destroying McDonald's restaurants, which were seen as symbols of globalization, and torching cultivated fields run by the multinational Monsanto (Udayagiri\& Walton, 2003). Gandhi would have obviously objected to such uses of violence. On the subject of globalization, Gandhi was hardly ever opposed to cultural transference across countries, and he would have found something even to celebrate in transfers across it. He was of the view that intermingling of cultures in India in the past served to strengthen the character of Indian culture to continue and to prosper across time spans. On the other hand, Gandhi was certainly opposed to consumerism. Production and trade in consumer goods was wastage to him; it was foreign to Indian traditions, and it distracted people from improving their spirit of existence. Consumption of industrial products was correct only so far as it was consumed to meet the basic needs of individuals. One might contrast the expansion of consumer goods available for consumption in the contemporary world with even the simple things Gandhi considered superfluous and so asked people to give up: cocoa, tobacco, alcohol, tea, coffee, spices, and all meat. He also asked people to shed superfluous articles of clothing like turbans, shoes, and jewels, and instead, he encouraged people to wear khadi or homespun clothes (Rivett, 1959).

In contemporary India, one might ask if the rural sector has been able to achieve an order of selfsufficiency, and get many answers. "Village republics" and "trusteeships of the rich" are still thrown around in political discourses of movements and agitation, but it has almost been extinguished from the institutional political system. At the same time, the uses of some Gandhian concepts have continued into the post-liberalization period. Gandhian environmentalists, such as 
the anti-globalization activist Vandana Shiva, have used Gandhi's concepts to stress the need to rediscover moral roots of using and exploiting environmental resources and to call for a return to the pre-capitalist and pre-colonial village society (Cochrane, 2007). Although Gandhian values continue to remain relevant in the contemporary Indian political economy, its disuse in institutional political discourses or economic programmes suggests the occurrence of a shift. Values and practices emerging from the neoliberal ideology of freeing the economy from State control have surpassed the traditional importance awarded to Gandhian values of 'balance' and 'frugality'.

\section{Gandhian Ideas and Neoliberal Economic Reforms}

Nehru's model of economic development that stood on the back of investments and production in State-controlled heavy industries was criticized from different quarters for arresting the rapid natural growth of the economy. The criticisms attacked the socialist economic policies operating between the 1950s and 1980s for failing to resolve India's problems of poverty and resource scarcities. Due to this, by 1991, a broad consensus emerged among India's thinkers, planners, and political leaders for liberalizing and opening up the economy (Ahluwalia, 2002). Some early economic reforms were begun in the 1980s but these picked up momentum and political sanction in the early 1990s. After 1997, there was support for faster and greater economic reforms almost across the political spectrum in India. These reforms generated new economic opportunities across the country. There were more avenues for making newer forms of profits and for running businesses with lesser constraints of multiple licenses and administrative hurdles.

The onset of the structural economic reforms in India was hailed as the death knell of Gandhian economic schemes (Nachane, 2016). It was a setback for Gandhian economists. Not only had Gandhi been against unbridled capital investments and increased trade and business, but the gradual withdrawal of the State from economic operations and the introduction of the free operation of the market destabilized the political space in India for economic justice delivery to its citizens. 
The operation of neoliberal economic policies was already creating disproportionate impacts across regions. Economic reforms forced by external institutional influences broke the backs of welfare states across Latin America and other third world countries in the 1980s. External institutional shock treatments were said to stimulate the functioning of efficient markets and thus save countries from ruin through debt. There was no evidence from across the world of neoliberal markets rewarding everyone efficiently (Udayagiri \& Walton, 2003). In subsequent times, in India, as in Latin American countries, reforms produced regressive consequences for poor and working economic classes. Cuts in subsidies and constrained government spending caused price instabilities of basic foods and increased private expenditures on health, education, and public transportation. Although incomes increased and poverty rates reduced, incomes did not keep up with the increase in prices. The privatization of economic sectors and limited government expenditure increased unemployment rates (Udayagiri \& Walton, 2003).

Adoption of the neoliberal political economy principles in India gradually erased all attachments to the Gandhian principle of frugality in private and public lives. With an increase of opportunities and taste for newer opportunities, some critics observed that increasing rationalization in economic choices had plunged humanity into an abyss of disenchantment (Arya, 2019). Rapid increases in economic growth rates in India did not directly fulfill the economic goals Gandhi set out for his country; instead combined factors of liberalization of the economy and withdrawal of the State from essential social sector responsibilities has led to a concentration of economic, cultural, and social capital in the hands of a few. This was the opposite of what Gandhi envisioned. The emerging new political society seemed to second the new visions for the Indian political economy. There was newly found faith in the justness of the withdrawal of the State from the market economy and in the efficiency of markets in distributing social rewards and punishments. Whereas consumerism was akin to poison in the Gandhian vision, consumerism, and faith in instrumental rationality have become defining characters of the political economy in India since the 1990s (Arya, 2019).

Scholars such as Pederson (2000) have elaborated on the hollowness of how neoliberal reforms have attempted to fulfill core Indian constitutional ideals of economic justice. Traditional public values of frugal consumption, altruism, and regular community service were abandoned to make 
way for new public goals of 'prosperity' and 'fast growth rates'. The rural sectors took a beating as burgeoning new middle classes displayed an appetite for "conspicuous consumerism", and the government responded to these demands for newer consumption by releasing the "animal spirits" of the economy. Urban trade and industrial manufactures rushed in and competed within and across sectors to supply the growing thirst for consumption.

\section{Withdrawal of the Gandhian Welfare State}

Gandhian ideals have influenced government initiatives and the model of the welfare state in India, but since the 1980s, the Indian welfare state model itself has been changing. The nature of interactions of public policies with Gandhian thoughts has also been changing, so that policies have awarded less importance to the practical implementation of Gandhian economic ideas and more importance to the moral character of his ideals. The collapse of the Indian socialist welfare state model existing until the 1990s and its substitution by the market-oriented free economy were reasoned to the more efficient working of the neoliberal development model. Sen (1977), for example, illustrated that the liberal economic development model based upon rational choices was operating upon a belief that all human beings looked to maximize their own gains at the expense of others.

The fundamental theory supporting the liberal model radically differed from the fundamental premises of Gandhi, which derived from the faith that economic attitudes are linked to the ultimate goals of spiritual exploration, and every person supports every other person in the shared goal of attaining spiritual revelation. Another key principle of the liberalized model was all people entered the free market as equal and free individuals. However, in reality, the operation of this model in India since the 1990s demonstrated that some people were able to disproportionately benefit from opening up the economy, while for some others, the liberalization was a bane rather than a boon.

The liberal model led to the emergence of differences in the ways capital and infrastructure resources were accessed. For example, higher investments in machinery and equipment enhanced the potential for churning out profits in the rural sector, but only large landowners were 
able to profit from technological advances. Cultivation of High Yield Variety crops, access to water supply, irrigation facilities and power, and to fertilizers and pesticides at affordable prices enabled some farmers to generate profits while acquisitions or transfers of lands belonging to poor and landless cultivators in some states displaced them from traditional sources of income. Thus, the liberal model did not help the State create a level playing field for all classes in the rural sector.

The growth of consumption in India did not arrest rises in prices of essential agricultural commodities. Growth in the production of cereals, pulses, milk, edible oil, sugar, tea, and cotton, etc. remained low. Phenomenal growth rates were registered in manufactured goods and sales of industrial items such as air conditioners, refrigerators, TVs, automobiles and motorcycles, and mobile phones, etc (Sen, 1997). The government continued implementing long-term poverty alleviation programmes to remove families from poverty. It was clear promises of the modern industrialized economy envisioned by Nehru, and later the free market economy since the 1990s, for resolving the social and economic problems of India were failing (Sen, 1997).

In the urban sectors, the rapid growth of industries in India through the 1990s and 2000s raised new concerns over a displacement of workers and artisans from traditional jobs. The huge economic changes caused new labor relations to emerge, making it easier for industries and companies to hire and fire workers as companies wished. Responsibilities of the State for labor relations and regulation of working conditions, however, remained unchanged. This resulted in making the lives of industrial workers difficult and subjected to uncertain living conditions (Sen, 1997). The operation of a great number of polluting and non-polluting industries in India since the 1990s would have saddened Gandhi. But if the operation of machine industries were found necessary for basic human functions, Gandhi would have recommended the use of such intermediate technologies so that more labor surpluses could be absorbed.

\section{Conclusion}

Gandhian economic thoughts reflected his deep spirituality and his empathy for the poor and the weak. His views on economic production in India can be seen in opposition to industrialization and the use of machines for increasing production capacities. He believed industrialization was 
leading to the exploitation of laborers, the marginalized, and the poor. The possible rationale behind this belief was that increased employment of people in modern industries would displace labor from traditional village industries and agricultural work, and ultimately lead to a perpetual dependence of the rural sectors on the urban centers.

As a socialist, he asserted that industries should aim to reduce the necessities of tough and unnecessary hard labor. There ought to be limits on how much income individuals might make, and excess income should be voluntarily returned to the State for redistribution in society. In his thinking, the State should also be given the responsibility to oversee equal and uniform development of people across social divisions in society. The Gandhian ideas had a deep impact on the freedom movement in India and on movement leaders who became ministers in the government. Gandhi's ideas were made into political programmes such as for boycott of foreignmade products and endorsement of Swadeshi goods.

Although in the contemporary Indian political economy, the influence of Gandhian ideas can still be seen in policies seeking to protect village industries from damage by the impact of modern industries, and in rights protecting the dignity of labor, the influence of his ideas has been passing into the space of moral influence from that of practical policies. It might be said that due to changes in the economic preferences of people in India in recent decades, Gandhian economic concepts have been losing their relevance amongst the political class, so that there is now a consensus on releasing the animal spirits of the Indian economy, rather than on meeting the Gandhian ideals of frugal consumption and disciplined living.

\section{Acknowledgments}

I am thankful to the two reviewers and Felicity Hand for their comments on the draft, and to David Prendergast for the elaborate copyediting. The usual disclaimers apply.

\section{WORKS CITED}

AHLUWALIA, M. S. (2002). "Economic Reforms in India since 1991: Has gradualism worked?", Journal of Economic Perspectives, 16 (3), 67-88. 
CHAKRABARTY, B. (1992). "Jawaharlal Nehru and Planning, 1938-41: India at the Crossroads", Modern Asian Studies, 26 (2), 275-287.

COCHRANE, R. (2007). "Rural Poverty and Impoverished Theory: Cultural Populism, Ecofeminism, and Global Justice", The Journal of Peasant Studies, 34:2, 167-206. https://doi.org/10.1080/03066150701516674

CHOWDHRY, K. (1988). “Growth or Survival?”, India International Centre Quarterly, 15(4), 191-200.

GANDHI, M. (1933). Hind Swaraj or Indian Home Rule. Ahmedabad: Navajivan Publishing House.

GANDHI, M. (1954) Mahatma: Life of Mohandas Karamchand Gandhi, Volume VIII (194748). Bombay: Vithalbhai K. Jhaveri \& D. G. Tendulkar.

IYENGAR, S., DOSHI, P. T. \& DESAI, H. (2012). “Gramdan to Gram Swaraj: Insights from Rajasthan Experiments", Gandhi Marg, 34 (1), 67-86.

JODHKA, S. (2002). "Nation and Village: Images of Rural India in Gandhi, Nehru, and Ambedkar", Economic and Political Weekly, 37 (32), 3343-3353.

KUMARAPPA, J. C. (1951). Gandhian Economic Thought. Varanasi: Sarva Seva SanghPrakashan.

MISRA, S. \& RAJIV, S. (2002). "Revitalising Panchayati Raj-Away From Gram Swaraj" In MISRA, A. D. (Ed) Rediscovering Gandhi, New Delhi: Mittal Publications.

NACHANE, D. M. (2016). "Gandhian Economic Thought and Its Influence on Economic Policymaking in India”, Indian Journal of Economics, Vol. XCVII, No. 384: 16-28.

NANDA, B. R. (1994). Gandhi and His Critics. New Delhi: Oxford University Press.

PARIKH, D. and PETRIE, C. A. (2019). "'We are Inheritors of a Rural Civilisation': Rural Complexity and the Ceramic Economy in the Indus Civilisation in Northwest India", World Archaeology, 51 (2), 252-272.

PEDERSEN, J. D. (2000). "Explaining Economic Liberalization in India: State and Society Perspectives", World Development, 28 (2), 265-282.

PRIYA, A. (2019). The Impact of Development on the Environment and Human Rights: A Study of Three Indian Projects. Newcastle: Cambridge Scholars Publishing. 
RIVETT, K. (1959). "The Economic Thought of Mahatma Gandhi", British Journal of Sociology, 10 (1): 1-15.

SEN, A. K. (1977). "Rational Fools: A Critique of the Behavioral Foundations of Economic Theory", Philosophy and Public Affairs, 6 (4), 317-344.

SEN, R. K. (1997). "Level of Living and Gandhian Economic Theory", International Journal of Social Economics, Vol. 24, No. 7/8/9, 791-798.

UDAYAGIRI, M., \& WALTON, J. (2003). "Global Transformation and Local Counter Movements: The Prospects for Democracy under Neoliberalism", International Journal of Comparative Sociology, 44(4), 309-343.

TAZ MAZINDER BARUA is UGC Junior Research Fellow and PhD scholar at Department of Political Science, Gauhati University Assam. 